\title{
Glide avalanche response to an extreme rain-on-snow event, Snoqualmie Pass, Washington, USA
}

\author{
John STIMBERIS, ${ }^{1}$ Charles M. RUBIN ${ }^{2 *}$ \\ ${ }^{1}$ Washington State Department of Transportation, Snoqualmie Pass, Washington 98068, USA \\ ${ }^{2}$ Department of Geological Sciences, Central Washington University, Ellensburg, Washington 98926, USA \\ E-mail: charlier@geology.cwu.edu
}

\begin{abstract}
Rain-on-snow events trigger immediate and delayed avalanches as liquid water penetrates the snowpack. We present results from an extreme rain-on-snow event that triggered a glide avalanche near Snoqualmie Pass, Washington, USA. Snoqualmie Pass recorded $463 \mathrm{~cm}$ of snowfall from 13 December 2008 to 6 January 2009. This period of snowfall was followed by a strong southwesterly tropical flow that resulted in an extreme rain-on-snow event. Sensors at Snoqualmie Pass recorded $\mathbf{2 8 5} \mathrm{mm}$ of precipitation over a $\mathbf{5 2}$ hour period. Flooding, slush flows, landslides and avalanches resulted from the influx of precipitation. Snow heights decreased rapidly over the period, with settlement rates approaching $80 \mathrm{~mm} \mathrm{~h}^{-1}$. Liquid water infiltrated and flowed through the snowpack within a few hours of the arrival of rain, yet many of the major avalanches occurred 12-30 or more hours after the onset of rain and water outflow. A glide avalanche occurred $\sim 30$ hours after the onset of rain and the establishment of drainage through the snowpack. Increasing glide rates correlate with periods of rapid snow settlement. Here glide rates approached $670 \mathrm{~mm} \mathrm{~h}^{-1}$. Although glide and settlement rates increased during periods of intense precipitation, glide failure occurred 8 hours after peak precipitation and outflow.
\end{abstract}

\section{INTRODUCTION}

Rain-on-snow is one of the major causes of winter snow avalanches in maritime climates and commonly triggers varying types of immediate and delayed avalanches (e.g. Conway and others, 1989; Heywood, 1989; Conway and Raymond, 1993; Osterhuber and Kattelmann, 1998; Ferguson, 2001). In the Pacific Northwest of North America, glide avalanches are commonly triggered by rain-on-snow events as liquid water penetrates the snowpack (McClung and others, 1994; Clarke and McClung, 1999). Due to evolving spatial distribution of liquid water in the snowpack, accurate forecasting is difficult. Although glide avalanches triggered by rain-on-snow events are well documented (e.g. Lackinger, 1987; McClung and others, 1994; Clarke and McClung, 1999), it is still uncertain how the timing of liquid water penetration into the snowpack triggers glide avalanches (Colbeck, 1978, 1979, 1991; Kattelmann, 1987). Changing climate has increased rain-on-snow events along the Cascade Mountain crest (McCabe and others, 2007) and is one of the major causes of winter snow avalanches. The high rate of avalanche activity and repeatable glide events at Snoqualmie Pass, Washington, USA (Fig. 1), provides an exceptional opportunity to characterize glide avalanche processes.

Here we present results from an extreme rain-on-snow event that triggered a full-depth glide avalanche near Snoqualmie Pass (Fig. 1) and discuss the relations between the onset of rain-on-snow and full-release glide failure. Our goals are to characterize avalanche processes and weather variables that influence the onset and eventual release of glide avalanches.

*Present address: Earth Obervatory, Nanyang Technological University, Singapore

\section{STUDY AREA}

The study area, Rockface, is located $2.5 \mathrm{~km}$ north-northwest of Snoqualmie Pass, at 1055 ma.s.l. (Fig. 1) in the central Cascade Mountains. The area has a maritime snow climate that is characterized by heavy winter snows and mild temperatures (Mock and Birkeland, 2000; McClung and Schaerer, 2006). Based on a 60 year average, the annual winter snowfall at nearby Snoqualmie Pass (921 ma.s.l.) is $11 \mathrm{~m}$, with nearly $2500 \mathrm{~mm}$ of precipitation annually.

Rockface has a northeast aspect and an average slope of $35^{\circ}$ (Fig. 2). The site is adjacent to the Alpental Ski Area, and the historic runout is capable of reaching beginner ski trails (Figs 1 and 2). Avalanche control on Rockface has been generally unsuccessful, similar to other glide avalanche slopes (Jones, 2004).

\section{Meteorological and snowpack observations}

Meteorological and snowpack data come from the Washington State Department of Transportation (WSDOT) snow study site on Snoqualmie Pass (Fig. 1). Both manual and automated observations are gathered from this site. Manual observations occur once daily. These include new HN24 (new snow deposition over a 24 hour period) and total snow or HS (height of snowpack), snow density, snow water equivalent (SWE) and a snow stability profile. Instrumentation includes HN24 and HS measured with ultrasonic depth sensors, precipitation, air temperature, atmospheric pressure and relative humidity. Water outflow from the snowpack is measured with a lysimeter (e.g. Martinec, 1987; Carran and others, 2001; Conway, 2005). In addition, glide data were collected at the Rockface site (Stimberis and Rubin, 2005). In this paper, we concentrate on a 27 day period from 13 December 2008 to 8 January 2009 and focus on the 6-8 January 2009 rain-on-snow event. 

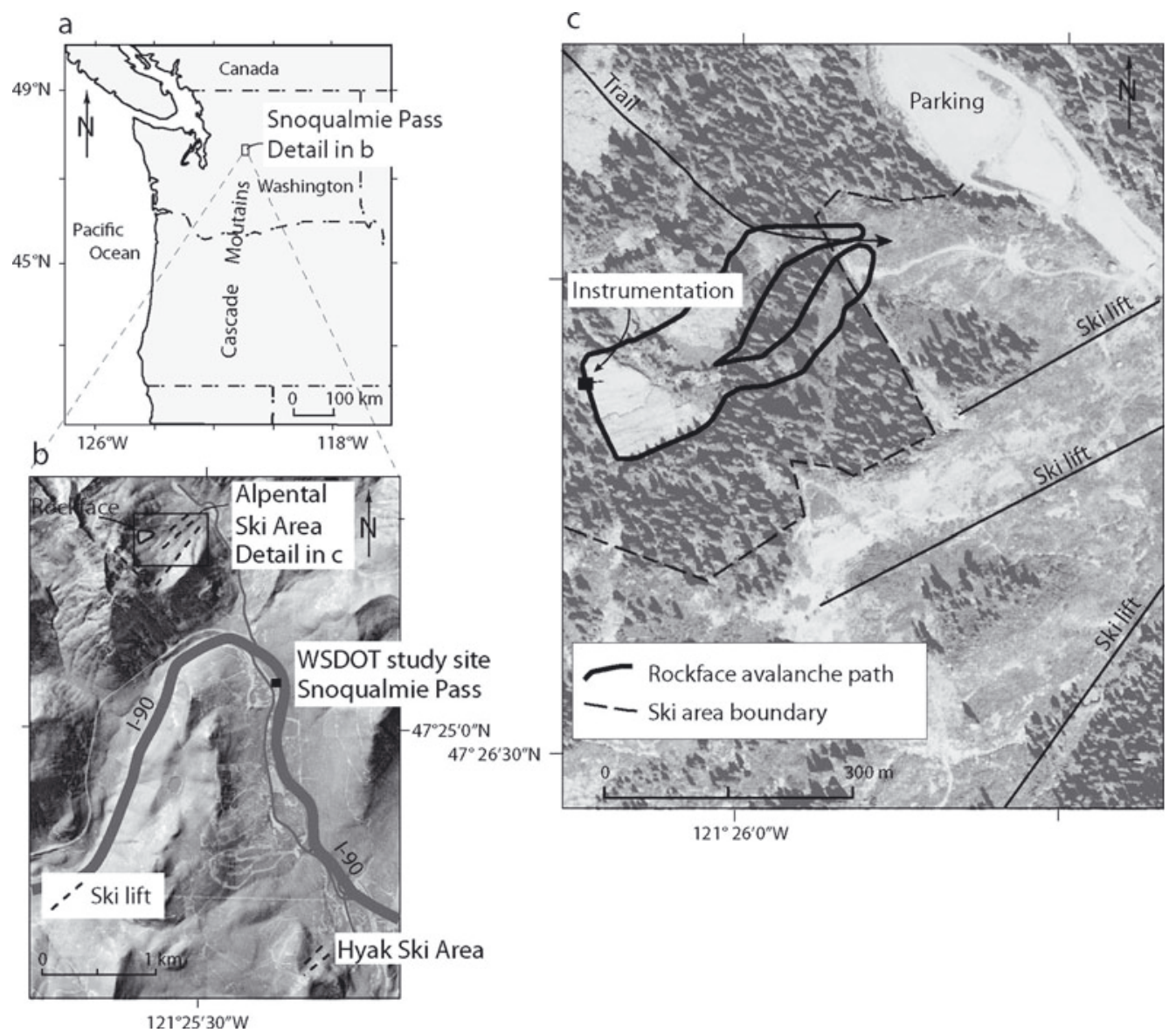

$121^{\circ} 26^{\circ} 0^{\prime \prime} \mathrm{W}$

Fig. 1. (a) Location map of Snoqualmie Pass, Cascade Mountains, Washington. (b) Location of Interstate-90 (I-90), Alpental Ski Area (976 m a.s.l.), Hyak (1035 ma.s.I.) and WSDOT study plot (921 ma.s.l.). (c) Map showing Rockface (1055 ma.s.l.), instrumentation and Alpental Ski Area boundary.
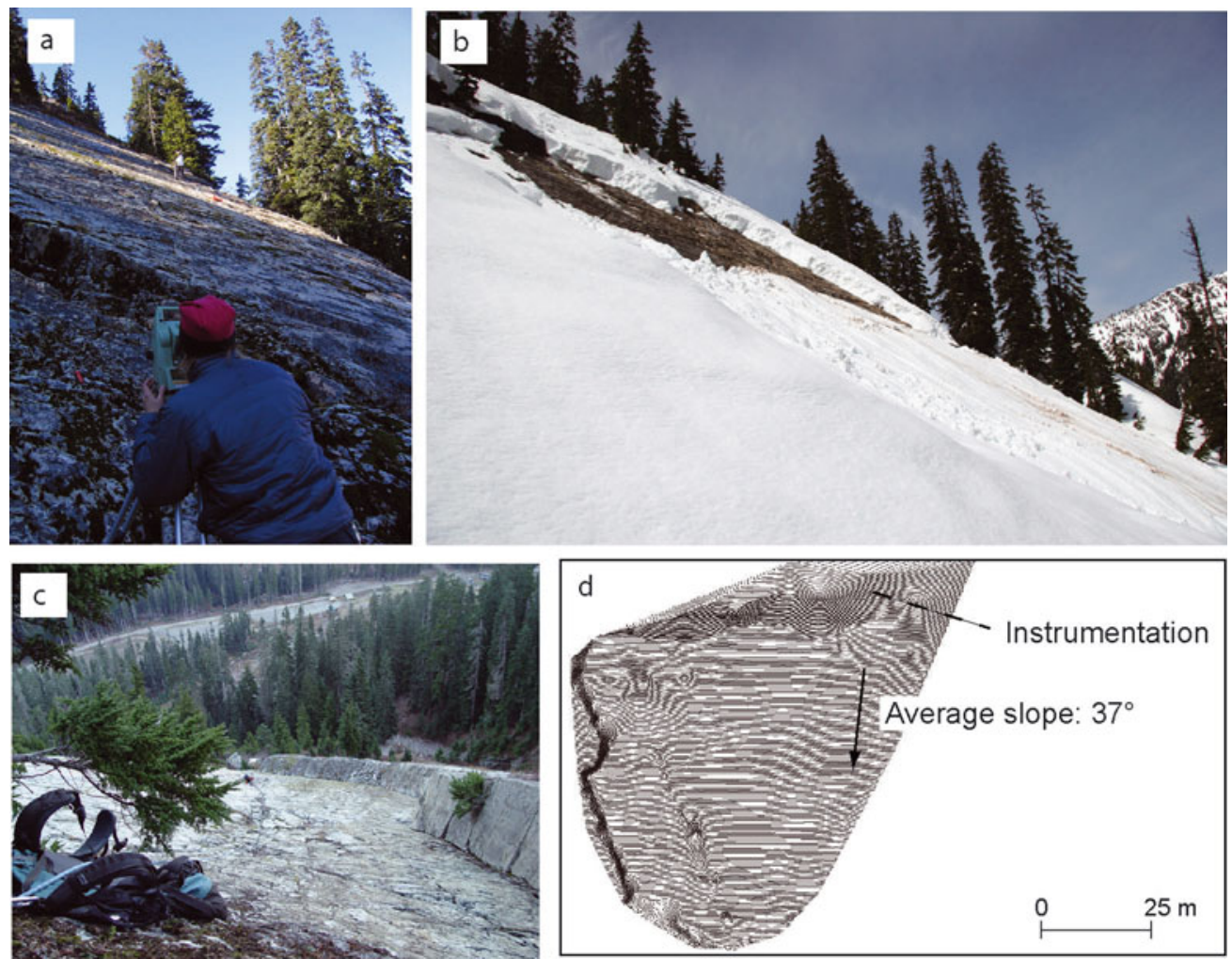

Fig. 2. (a) Surveying Rockface with a total station. A topographic map provides detail on the surface characteristics such as slope angle, major fractures and fluid channelways. (b) Looking towards a glide crack and a small glide-related avalanche at Rockface. (c) Looking down Rockface towards the public parking lots and the Alpental road. (d) Detailed topographic map of Rockface $(20 \mathrm{~cm}$ contours). 


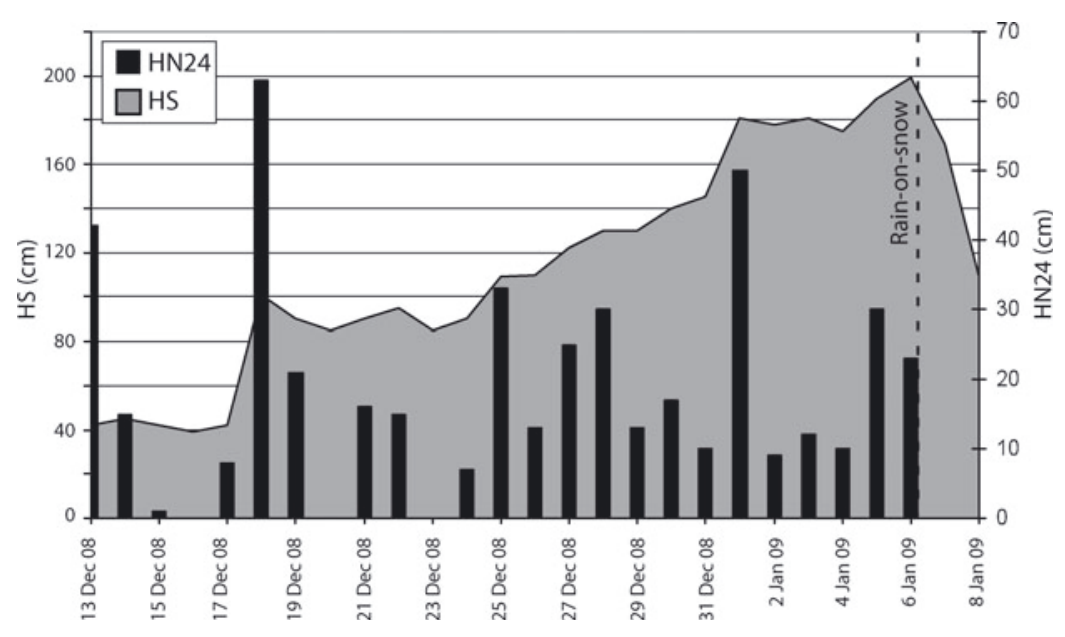

Fig. 3. Height of snowpack between 12 December 2008 and 6 January 2009. Over $460 \mathrm{~cm}$ of snow (465.2 mm SWE) were recorded over a 25 day period between 13 December 2008 and 6 January 2009. Prior to the rain-on-snow event, snow density was $\sim 230 \mathrm{~kg} \mathrm{~m}^{-3}$.

\section{Early-winter observations}

The winter of 2008/09 began in earnest on 13 December 2008 when a storm deposited $57 \mathrm{~cm}$ of snow $(47.8 \mathrm{~mm}$ snow water equivalent (SWE)) over a 36 hour period. This storm was followed in quick succession by additional storms of varying intensity including $63 \mathrm{~cm}$ of snow (45.9 mm SWE) during one 24 hour recording period. Over $460 \mathrm{~cm}$ of snow (465.2 mm SWE) were recorded over a 25 day period between 13 December 2008 and 6 January 2009 (Fig. 3).

Temperatures were below average for the region between 13 December 2008 and 6 January 2009, with sub-freezing temperatures and snowfall reported down to sea level. Temperatures at the WSDOT study plot dropped as low as $-18^{\circ} \mathrm{C}$ during this period, though low temperatures averaged about $-10^{\circ} \mathrm{C}$. Two brief periods of rain were recorded, though the events were short-lived and did not penetrate the entire snowpack. Two thin crusts formed in the snowpack as a result of the brief rain events. Temperature gradients within the snowpack were $\sim 0.2^{\circ} \mathrm{Cm}^{-1}$. Overall, the snowpack was relatively cold and unconsolidated for a maritime region. Avalanches and avalanche control occurred throughout the early-winter period. The WSDOT performed
14 highway avalanche control operations during late December to early January.

\section{January 2009 rain-on-snow event}

By early January, weather forecasters at the US National Weather Service (NWS) identified a strong Pacific storm system forming in the subtropical regions. These systems, referred to as a 'Pineapple Express', can produce ample amounts of rain, high temperatures and flooding. By the evening of 4 January 2009 the storm system reached Washington State. The first 36 hours produced $53 \mathrm{~cm}$ of snow (74.6 mm SWE) (Fig. 3). By the morning of 6 January 2009, the warm front, combined with a strong jet stream, reached the region and snow turned to rain. A rain-on-snow event was unfolding and NWS forecasters were expecting a record-setting event.

Avalanche paths near Snoqualmie Pass produced minor avalanche activity at the onset of rain. The WSDOT studyplot snow lysimeter indicated that liquid water began to flow from the snowpack $\sim 3$ hours after the onset of rain (Fig. 4). About 12 hours after the onset of rain, WSDOT avalanche forecasters assumed the snowpack was beginning to stabilize

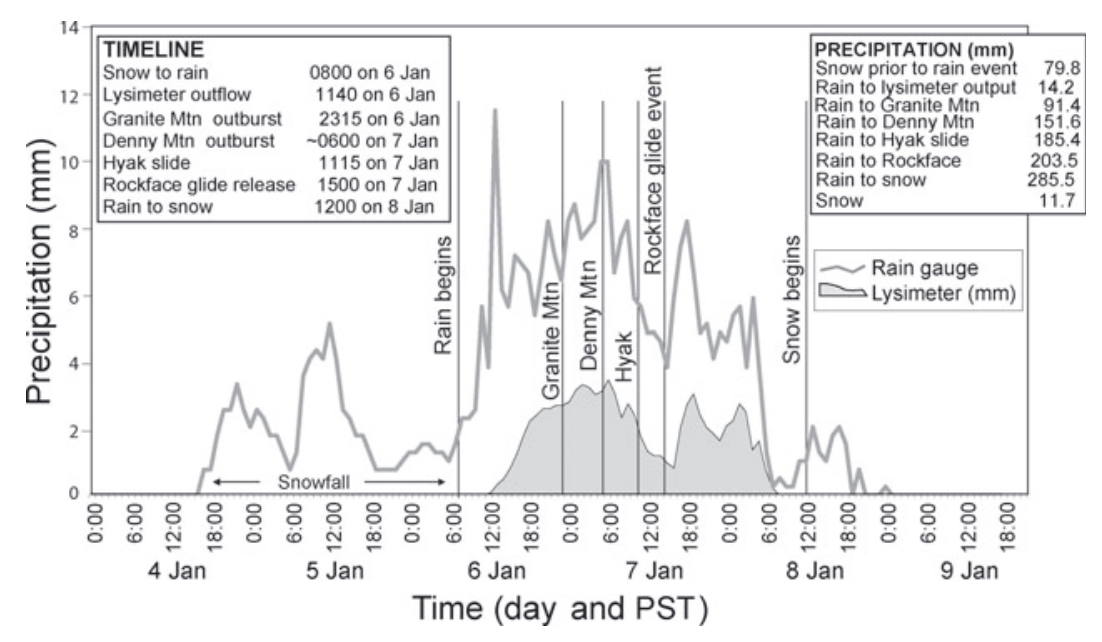

Fig. 4. Precipitation and outflow between 4 and 9 January 2009. Note the lag time between rainfall and outflow from snowpack. The delay between the onset of rain and outflow was $>3$ hours. Rainfall was perhaps three to four times greater than outflow. The first class 3 avalanche occurred $>15$ hours after the onset of rain. Over 32 hours elapsed between the onset of rain and the glide avalanche at Rockface. 
and no avalanche control was scheduled. Previous work suggests that avalanche release is rare after drainage through a snowpack has been established, even during continued rain (Conway and Raymond, 1993; Conway, 2005).

At $2300 \mathrm{~h}$ Pacific Standard Time (PST), 15 hours after the rain began and nearly 12 hours after the lysimeter began recording water outflow from the snowpack, the first major avalanche initiated at $1035 \mathrm{ma.s.l}$. (Fig. 4) at Granite Mountain. This avalanche occurred after $91 \mathrm{~mm}$ of rain and $21 \mathrm{~mm}$ outflow from the snowpack. The avalanche path follows a stream bed and produced a massive flow of snow, ice, rock and trees that blocked the highway $(730 \mathrm{~m})$. The highway was closed to traffic, and over the next few hours massive amounts of water began to inundate the highway. An additional slush avalanche was reported around $0200 \mathrm{~h}$ PST on 7 January 2009, on the road to the Alpental Ski Area (Fig. 1).

At 0600 h PST on 7 January 2009, nearly 24 hours after the rain began, another substantial influx of snow, rocks, ice and trees covered the highway along a stream bed where avalanches have not been previously observed. Instruments at the WSDOT study plot had recorded $152 \mathrm{~mm}$ of rain and $43 \mathrm{~mm}$ of outflow by this time (Fig. 4). By $1100 \mathrm{~h}$ PST on 7 January 2009, a landslide released at the Hyak Ski Area (1035 $\mathrm{m}$ a.s.I.; Figs 2 and 4), destroying a house and the main chairlift (Fig. 5). About $185 \mathrm{~mm}$ of rain and $55 \mathrm{~mm}$ of outflow were recorded by the time the Hyak slide occurred. The Hyak event occurred 24 hours after the first outflow of water was recorded by the lysimeter. At $1500 \mathrm{~h}$ on 7 January 2009, a glide avalanche was recorded at Rockface after nearly $205 \mathrm{~mm}$ of rain and $60 \mathrm{~mm}$ of outflow (Fig. 4). By the time the storm ended, the January 2009 rain-on-snow event was classified as an extreme event, with a return period in excess of 100 years (personal communication from B. Bower, 2009).

\section{SNOW GLIDE}

Air-temperature, precipitation, snowpack drainage and snow-depth data were collected in $15 \mathrm{~min}$ intervals at the WSDOT Snoqualmie Pass study plot (Fig. 1). Glide rates on Rockface were collected in $30 \mathrm{~s}$ intervals using a Celesco linear extension transducer (Stimberis and Rubin, 2005). Since visibility was generally poor and flooding damaged the road to the Alpental Ski Area (Fig. 1), no physical observations of Rockface were made during the rain-onsnow event.

During the rain-on-snow event, air temperature and rainfall at the Snoqualmie Pass study site were similar to temperatures and rainfall recorded at the Alpental instrument site $(976 \mathrm{~m}$ a.s.I.). During the time of the Rockface glide event, air temperature remained several degrees above $0^{\circ} \mathrm{C}$ for $>32$ hours and received $>60 \mathrm{~mm}$ of rainfall. Due to above-freezing temperatures and substantial rainfall, glide deformation was concentrated along the wetted snow/ rock interface.

\section{Glide response to a rain-on-snow event}

Glide rates were minimal during the initial period of snowfall from 4 to 5 January 2009. Over a 19 hour period, $38 \mathrm{~cm}$ of snow fell (49 mm SWE) and $<20 \mathrm{~mm}$ of glide/creep were recorded (Figs 4 and $6 \mathrm{a}$ ). An additional $3.5 \mathrm{~cm}$ of snow (19 mm SWE) was recorded over the next 12 hours from 1200 to $2400 \mathrm{~h}$ PST on 5 January. The increasing density of the snow likely contributed to glide/creep acceleration as

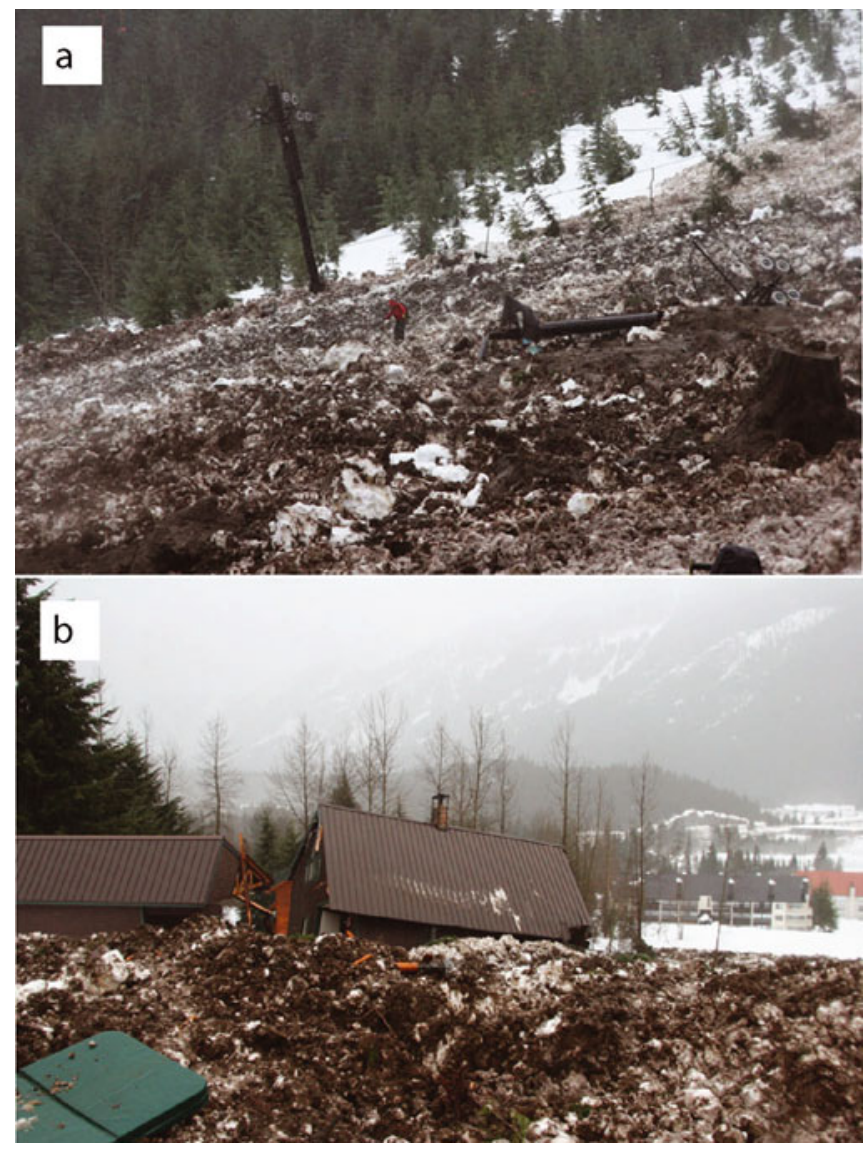

Fig. 5. Rain-on-snow event triggered an earthflow mixed with snow, Hyak Ski Area (location shown in Fig. 1b). (a) Destroyed lift tower, Hyak Ski Area. (b) Damaged houses within the avalanche run-out zone.

the Rockface glide sensor recorded an additional $300 \mathrm{~mm}$ of movement during that 12 hour period (Figs 4 and 6a). The HS experienced no net change during this period and temperatures averaged $0^{\circ} \mathrm{C}$.

By $0800 \mathrm{~h}$ PST on 6 January, snow had changed to rain. An additional $110 \mathrm{~mm}$ of glide/creep occurred between 0000 and $0800 \mathrm{~h}$ PST on 6 January (Figs 4 and 6a). Precipitation rates increased rapidly as the warm front moved over the area. Rainfall became heavy, averaging $7 \mathrm{~mm} \mathrm{~h}^{-1}$ and peaking at $12.5 \mathrm{~mm} \mathrm{~h}^{-1}$ over the next 24 hours (0800 h PST on 6 January to $0800 \mathrm{~h}$ PST on 7 January). Air temperatures remained fairly consistent during the period, with a general warming trend after the onset of rain, reaching a maximum of $5^{\circ} \mathrm{C}$. Glide/creep motion remained low and consistent during 6 January, averaging $6 \mathrm{~mm} \mathrm{~h}^{-1}$ with little variation in rate. The HS decreased $\sim 16 \mathrm{~cm}$ during the 8 hour period $\left(\sim 20 \mathrm{~mm} \mathrm{~h}^{-1}\right)$ prior to the onset of rain (Fig. 4). Glide increased by the end of 6 January and into the following day as glide rates accelerated and became increasingly erratic.

Precipitation rates of $7 \mathrm{~mm} \mathrm{~h}^{-1}$ on 7 January remained similar to the previous day, though there was a general decrease in intensity for a few hours prior to the glide avalanche. Outflow also decreased during this period. Air temperatures decreased to a minimum of $2.5^{\circ} \mathrm{C}$ and averaged $\sim 3.3^{\circ} \mathrm{C}$ prior to the avalanche (Fig. 4). An additional $40 \mathrm{~cm}$ of snow settlement at an average rate of $27 \mathrm{~mm} \mathrm{~h}^{-1}$ occurred on 7 January before the glide avalanche released. Between the onset of rain and the glide avalanche on Rockface, the 

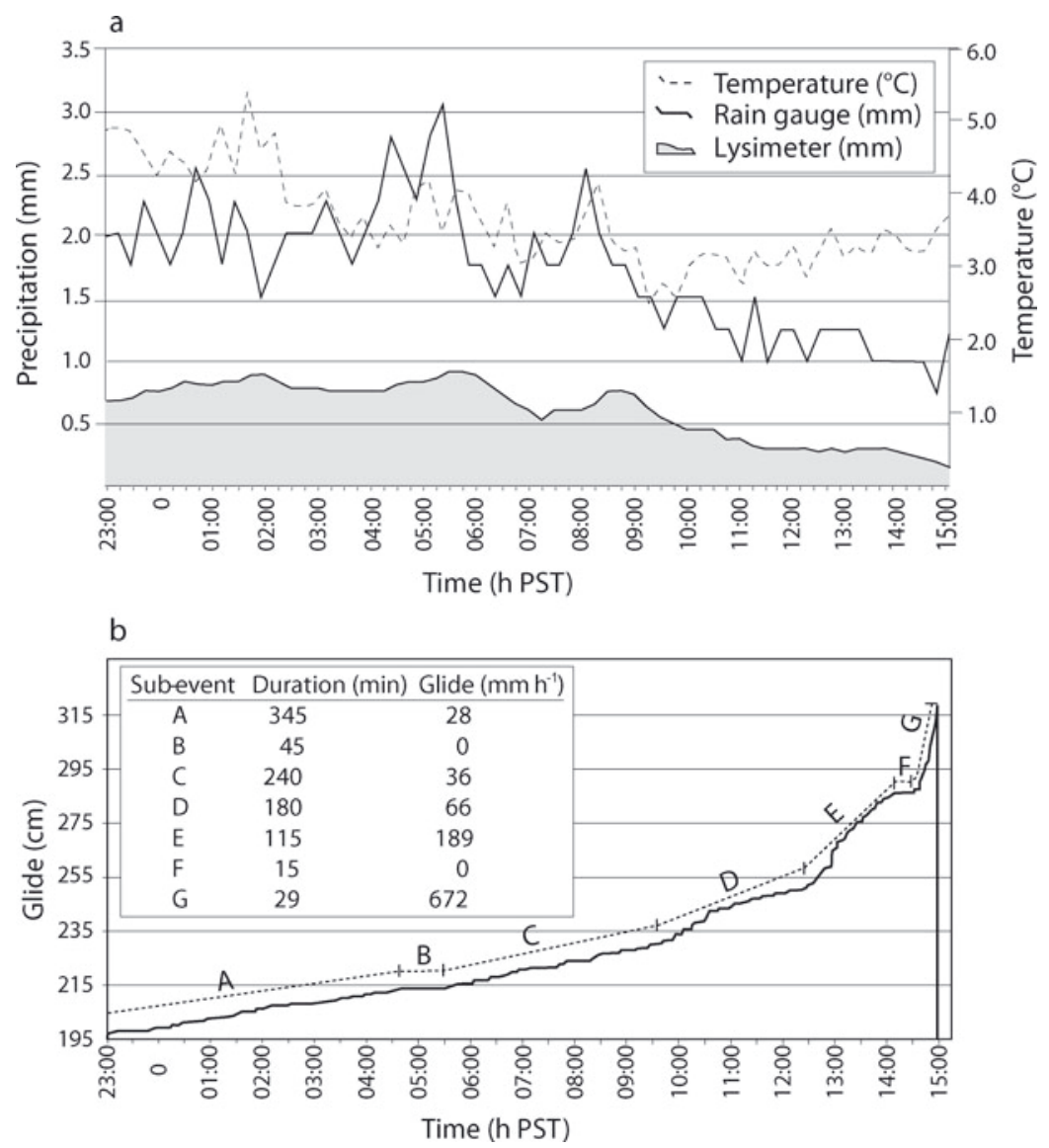

Fig. 6. (a) Precipitation, temperature and outflow, 2300 h PST 6 January 2009 to 1500 h PST 7 January 2009. Air-temperature, precipitation and snow-depth measurements are collected at 15 min intervals. Lysimeter data are recorded every 5 min. (b) Cumulative glide and subevents A-G between 6 and 7 January 2009. Glide sub-events are defined by changes in glide rate. Before full-release failure, glide rates average $>670 \mathrm{~mm} \mathrm{~h}^{-1}$.

WSDOT study plot recorded $>200 \mathrm{~mm}$ of precipitation and $60 \mathrm{~mm}$ of outflow. The HS also decreased nearly $600 \mathrm{~mm}$ during that period. Over the 60 hour rain-on-snow event, the HS decreased >900 mm (Fig. 4).

\section{DISCUSSION}

Rain-on-snow events occur most frequently during January in the Pacific Northwest (McCabe and others, 2007) and are responsible for avalanche release, initially triggering avalanches within minutes of rainfall (Conway and Raymond, 1993). Continued rainfall may trigger deeper avalanches over an extended period (Conway, 2005). During the January 2009 event, a glide avalanche occurred $>32$ hours after the onset of rain.

Based on variations in glide/creep rate and acceleration over a 16 hour period, we identified seven distinct glide subevents (Fig. 6b). The first sub-event (sub-event A) is characterized by a constant glide rate of $\sim 28 \mathrm{~mm} \mathrm{~h}^{-1}$ and lasted nearly 5 hours. Sub-event A marks the first prolonged period of snow glide on Rockface since the onset of rain. Here the onset of glide correlates with the above-freezing temperatures and the presence of liquid water at the snow/ ground interface (Fig. 6b).

Sub-event B marks the cessation of motion for $\sim 45 \mathrm{~min}$ (Fig. 6b). During this pause, $8.1 \mathrm{~mm}$ of rain and $2.5 \mathrm{~mm}$ of outflow were recorded. Snow settlement increased from 11 to $36 \mathrm{~mm} \mathrm{~h}^{-1}$ during sub-event B.
Sub-event $\mathrm{C}$ is distinguished by erratic or stick-slip motion for $>4$ hours (Fig. 6b). Precipitation and water outflow slowly declined during this sub-event (Fig. 2). Similar fluctuating glide motion was observed in the Swiss Alps (In der Gand and Zupaničič, 1966). Air temperature decreased by $1.6^{\circ} \mathrm{C}$ through the 4 hour period. The end of sub-event $C$ marks the lowest air temperature recorded during the remaining rain-on-snow event.

Sub-event $\mathrm{D}$ is characterized by an increasing glide rate of $\sim 189 \mathrm{~mm} \mathrm{~h}^{-1}$ (Fig. 6b) and HS decreases $\sim 14 \mathrm{~cm}$ at a rate of $46 \mathrm{~mm} \mathrm{~h}^{-1}$. Air temperatures remain stable, averaging $3{ }^{\circ} \mathrm{C}$. Precipitation averages $\sim 5 \mathrm{~mm} \mathrm{~h}^{-1}$, beginning a relative lull before the next front reaches the area.

Similar temperature and precipitation trends continue into sub-event E. Glide rates substantially increase during this sub-event (Fig. 6b), with an average of nearly $190 \mathrm{~mm} \mathrm{~h}^{-1}$. Over $90 \mathrm{~mm}$ of glide occurs during one $7 \mathrm{~min}$ period, only to be followed by episodes of limited glide. Snow settlement rates substantially decreased in the final 30 min of sub-event $\mathrm{E}$ and closely correlate with a decline of glide rate.

Sub-event F, a $15 \mathrm{~min}$ period, is defined by no glide motion or snow settlement (Fig. 6b). Average precipitation values are similar to the previous sub-event, and air temperatures remain the same.

After the short pause of glide and snow settlement rates, sub-event $\mathrm{G}$ is defined by a rapid acceleration of glide rate over a 30 min period before glide avalanche failure (Fig. 6b). Snow settlement substantially increased during the latter 
part of sub-event G. Precipitation and outflow rates decrease to the lowest level during the 16 hour glide event.

In the aftermath of the Rockface avalanche, precipitation rates and air temperatures increased gradually over the next 12 hours. On 8 January, air temperatures began to decrease and after several more hours the precipitation rates began to decline. No additional avalanches were reported in the Snoqualmie Pass area following the Rockface avalanche.

\section{IMPLICATIONS FOR GLIDE FAILURE}

The delay between the onset of rain and the avalanche at Rockface is similar to previous reports of delayed avalanches (Conway, 2005). At the time of the Rockface avalanche, rainfall was perhaps three to four times greater than outflow at the base of the snowpack (Fig. 4). Although glide deformation increases with lubrication along the snow/rock interface, water outflow from the snowpack does not always accurately forecast glide avalanches.

During periods of prolonged rain, delay between the onset of rain and failure might be longer than 32 hours. The weight of the additional water produced substantial gravitational loading of the snowpack. The delay between the onset of rain and failure is likely due to a combination of (1) the ground configuration of Rockface, (2) an increase of downslope stress due to additional loading from rain, and (3) the consolidation of the snowpack during the rain event. A rock dihedral intersects the smooth rock surface along the lower flank of the avalanche path (Fig. 2c). The snowpack upslope of the dihedral is often characterized by extensive buckling and bulging prior to glide avalanche release, indicating the dihedral provides sufficient buttressing to support the snowpack during the glide events that precede the glide avalanche release. Although our data show other short-period sub-events (e.g. sub-event E), rapid glide during sub-event G might represent a precursory event (Fig. 6b). Additional data are required before we can identify precursory short-period glide events.

The low air temperatures, averaging $-10^{\circ} \mathrm{C}$, prior to the rain-on-snow event produced a relatively unconsolidated snowpack that could readily anchor itself to the irregularities of the underlying rock. Subsequent snowpack settlement produced from creep driven by rising temperatures and rain results in a dense and cohesive snowpack. Applied stresses acting on the cohesive snowpack coupled with liquid water at the snow/ground interface will create a snow slab that will glide over bed surface irregularities. Thus, the combination of the bed surface and initial snowpack conditions exert fundamental control of avalanche timing during rain-onsnow events.

The interval between the onset of rain and failure raises important questions about the physical processes that control glide failure. In contrast to our understanding of non-Newtonian glacial dynamics where the Navier-Stokes equation describes the underlying physics, there is no general consensus about a correct model(s) that describes the motions of snow avalanches and snow glide (e.g. McClung, 1981; Kamb, 1987).

The interval between the onset of rain and failure raises important questions about the physical processes that control glide failure. Based on our studies, we suggest that glide motion occurs in three stages: (1) initiation of glide/sliding on a small portion of the slip surface, (2) growth of the slip surface by overcoming frictional resistance along asperities and (3) sudden change from stick-slip mode to rapid failure. Sudden failure occurs when the accumulated stress is higher than friction resistance along the snow-slab/ground interface.

During the January 2009 rain-on-snow event, the base of the snowpack was at the melting point. This might have allowed water pressure to build up under the snowpack. Increased water pressure perhaps lifted the snowpack above the underlying rock surface. Friction at the lateral shear margins (e.g. dihedral that intersects Rockface; Fig. 2) and bedrock bumps or irregularities under the snow that act as sticky spots prevented the glide velocity from cascading out of control. In this context, cyclic stick-slip might result in significant wear along the asperities on the base of the snow surface. The asperities act like anchors that hold a ship in the water; static friction counteracts the downslope stress. Asperities at the base of the snowpack might include ice lenses or crusts that are spatially distributed along the base of the snowpack. If the basal water-pressure controls slip, perhaps cyclic stick-slip glide is correlated with marked time variations in basal water pressure or water-flow velocity fluctuations.

Since stabilization generally occurs after drainage through the snowpack is well established, it is not surprising that avalanches occurred after substantial outflow from the base of the snowpack.

\section{ACKNOWLEDGEMENTS}

Our study was supported by the Department of Transportation, Washington State, and Central Washington University. We thank the Alpental Pro Patrol and Summit at Snoqualmie for providing access and field assistance. We thank P. Winberry for helpful discussions. H. Conway and S. Conger provided thoughtful reviews and helpful comments that substantially improved the manuscript. This is EOS contribution No. 27.

\section{REFERENCES}

Carran, W., S. Hall, C. Kendall, A. Carran and H. Conway. 2001. Snow temperature and water outflow during rain and melt, Milford Highway, New Zealand. In Proceedings of the International Snow Science Workshop, 1-6 October 2000, Big Sky, Montana, USA. Bozeman, MT, American Avalanche Association, 173-177.

Clarke, J. and D. McClung. 1999. Full-depth avalanche occurrences caused by snow gliding, Coquihalla, British Columbia, Canada. J. Glaciol., 45(151), 539-546.

Colbeck, S.C. 1978. The physical aspects of water flow through snow. In Chow, V.T., ed. Advances in Hydroscience, Vol. 11. New York, Academic Press, 165-206.

Colbeck, S.C. 1979. Water flow through heterogeneous snow. Cold Reg. Sci. Technol., 1(1), 37-45.

Colbeck, S.C. 1991. The layered character of snow covers. Rev. Geophys., 29(1), 81-96.

Conway, H. 2005. Storm Lewis: a rain-on-snow event on the Milford Road, New Zealand, Transit New Zealand Avalanche Program. In Elder, K., ed. Proceedings of the International Snow Science Workshop, 19-24 September 2004, Jackson Hole, Wyoming. Jackson Hole, WY, International Snow Science Workshop, 557-565.

Conway, H. and C.F. Raymond. 1993. Snow stability during rain. J. Glaciol., 39(133), 635-642.

Conway, H., S. Breyfogle and C.R. Wilbour. 1989. Observations relating to wet snow stability. In Proceedings of the International Snow Science Workshop, 12-15 October 1988, Whistler, British 
Columbia, Canada. Vancouver, BC, Canadian Avalanche Association, 211-222.

Ferguson, S.A. 2001. The spatial and temporal variability of rain-onsnow. In Proceedings of the International Snow Science Workshop, 1-6 October 2000, Big Sky, Montana, USA. Bozeman, MT, American Avalanche Association, 178-183.

Heywood, L. 1989. Rain on snow avalanche events: some observations. In Proceedings of the International Snow Science Workshop, 12-15 October 1988, Whistler, British Columbia, Canada. Vancouver, B.C., Canadian Avalanche Association, 125-136.

In der Gand, H.R. and M. Zupaničič. 1966. Snow gliding and avalanches. IASH Publ. 69 (Symposium at Davos 1965 Scientific Aspects of Snow and Ice Avalanches), 230-242.

Jones, A. 2004. Review of glide processes and glide avalanche release. Avalanche News 69, 53-60.

Kamb, B. 1987. Glacier surge mechanism based on linked cavity configuration of the basal water conduit system. J. Geophys. Res., 92(B9), 9083-9100.

Kattelmann, R. 1987. Some measurements of water movement and storage in snow. IAHS Publ. 162 (Symposium at Davos 1986 Avalanche Formation, Movement and Effects), 245-254.

Lackinger, B. 1987. Stability and fracture of the snow pack for glide avalanches. IAHS Publ. 162 (Symposium at Davos 1986 Avalanche Formation, Movement and Effects), 229-240.
Martinec, J. 1987. Meltwater percolation through an Alpine snowpack. IAHS Publ. 162 (Symposium at Davos 1986 Avalanche Formation, Movement and Effects), 255-264.

McCabe, G.J., M.P. Clark and L.E. Hay. 2007. Rain-on-snow events in the western United States. Bull. Am. Meteorol. Soc., 88(3), 319-328.

McClung, D.M. 1981. A physical theory of snow gliding. Can. Geotech. J., 18(1), 86-94.

McClung, D. and P. Schaerer. 2006. The avalanche handbook. Third edition. Seattle, WA, The Mountaineers.

McClung, D.M., S. Walker and W. Golley. 1994. Characteristics of snow gliding on rock. Ann. Glaciol., 19, 97-103.

Mock, C.J. and K.W. Birkeland. 2000. Snow avalanche climatology of the western United States mountain ranges. Bull. Am. Meteorol. Soc., 81(10), 2367-2392.

Osterhuber, R. and R. Kattelmann. 1998. Warm storms associated with avalanche hazard in the Sierra Nevada. In Proceedings of the International Snow Science Workshop, 27 September1 October 1998, Sunriver, Oregon. Olympia, WA, Washington State Department of Transportation, 526-533.

Stimberis, J. and C. Rubin. 2005. Glide avalanche detection on a smooth rock slope, Snoqualmie Pass, Washington. In Elder, K., ed. Proceedings of the International Snow Science Workshop, Jackson Hole, Wyoming, 19-24 September 2004. Jackson Hole, WY, International Snow Science Workshop, 608-610.

MS received 24 July 2010 and accepted in revised form 6 February 2011 